\title{
Analisis Beban Kerja Mental Operator Lantai Produksi Pabrik Kelapa Sawit Dengan Metode NASA-TLX di PT. Bina Pratama Sakato Jaya, Dharmasraya
}

\author{
Dewi Diniaty, ST., M.Ec.Dev ${ }^{1}$, Muhammad Ikhsan ${ }^{2}$ \\ 1,2 Jurusan Teknik Industri, Fakultas Sains dan Teknologi, UIN Sultan Syarif Kasim Riau \\ Jl. HR. Soebrantas No. 155 Simpang Baru, Panam, Pekanbaru, 28293 \\ Email: dewidiniaty, Ikhsanjoe7@gmail.com
}

\begin{abstract}
ABSTRAK
PT. Bina Pratama Sakato Jaya merupakan salah satu perusahaan yang bergerak dibidang perkebunan kelapa sawit. PT. Bina Pratama Sakato Jaya memiliki kapasitas 600 ton/hari atau $50.000 \mathrm{Kg}$ minyak mentah yang dihasilkan. Penelitian ini dilakukan terhadap operator lantai produksi yaitu pada stasiun Loading Ramp, Setrilizer, Tippler, Threshing, Press, Clarification, Nut \& Kernel dan Boiler, dimana pada mesin produksi ini memiliki satu operator setiap stasiun. Dari hasil observasi yang dilakukan di PT. Bina Pratama Sakato Jaya bahwasanya pada stasiun lantai produksi inilah pekerjaan yang harus memiliki ketelitian, mental dan tenaga yang tinggi dalam melakukan produksi. Pekerja harus bekerja selama 7 jam/hari. Tujuan dari penelitian ini adalah untuk mengetahui tingkat beban kerja mental dari operator lantai produksi PT. Bina Pratama Sakato Jaya dengan menggunakan metode NASA-TLX, yang diukur melalui 6 indikator yaitu kebutuhan fisik, kebutuhan mental, usaha, tingkat frustasi, kebutuhan waktu, dan performansi. Dari hasil pengukuran terhadap 8 orang operator lantai produksi mendapatkan nilai WWL kategori sangat tinggi yaitu Loading Ramp 92,6, Clarification 92,6, sedangkan kategori tinggi yaitu Setrilizer 76, Tippler 78, Threshing 77,3, Press 74, Nut \& Kernel 84,6 dan Boiller 72,0. Karena rata-rata beban kerja yang dialami tergolong tinggi, peneliti memberikan alternatif perbaikan diantaranya menambah karyawan dilantai produksi dan diberikan pelatihanpelatihan tentang kondisi pabrik dan kondisi mesin yang ada pada lantai produksi.
\end{abstract}

Kata Kunci: Beban Kerja Mental, Metode NASA - TLX, Operator lantai produksi

\section{Pendahuluan}

Pada zaman globalisasi saat ini, perusahaan dituntut untuk terus meningkatkan produktivitasnya, baik dari segi efektivitas maupun efisiensinya. Untuk meningkatkan hal tersebut, pada suatu proses produksi diperlukan pemberdayaan secara optimal sumber daya yang ada, terutama sumber daya manusianya.

Sumber daya manusia adalah salah satu aset perusahaan yang harus dikelola dengan baik karena sangat berpengaruh terhadap kinerja yang dihasilkan pada suatu perusahaan. Pengelolaan yang baik mengandung arti bahwa yang dihasilkan setiap karyawan dapat memenuhi apa yang telah ditargetkan oleh perusahaan.

Pada dasarnya, aktivitas manusia dapat digolongkan menjadi kerja fisik (otot) dan kerja mental (otak). Meskipun tidak dapat dipisahkan, namun masih dapat dibedakan pekerjaan dengan dominasi fisik dan pekerjaan dengan dominasi aktivitas mental. Aktivitas fisik dan mental ini menimbulkan konsekuensi, yaitu munculnya beban kerja. Beban kerja dapat didefinisikan sebagai perbedaan antara kemampuan pekerja dengan tuntutan pekerjaan (Widyanti, 2010)

Beban Kerja mental adalah kondisi kerja dimana informasi yang masih harus diproses di dalam otak. Kerja mental meliputi kerja otak dalam pengertian sempit dan pemrosesan informasi. Kerja otak dalam pengertian sempit adalah proses berfikir yang memerlukan kreatifitas, misalnya membuat mesin, membuat rencana produksi, mempelajari file dan menulis laporan. Beban kerja mental yaitu selisih antara tuntutan beban kerja dari suatu tugas dengan kapasitas maksimum beban mental seseorang dalam kondisi termotivasi (Mutia, 2014).

Penelitian ini dilakukan terhadap operator lantai produksi yaitu pada stasiun Loading Ramp, Setrilizer, Tippler, Threshing, Press, Clarification, Nut \& Kernel dan Boiler, dimana pada mesin produksi ini memiliki satu operator setiap stasiun. Dari hasil observasi yang dilakukan di PT. Bina Pratama Sakato Jaya bahwasanya pada stasiun lantai produksi inilah pekerjaan 
yang harus memiliki ketelitian, mental dan tenaga yang tinggi dalam melakukan produksi.

\section{Metode Penelitian}

Beban kerja adalah beban yang diterima pekerja untuk menyelesaikan pekerjaannya, seperti mengangkat, berlari dan lain-lain. Setiap pekerjaan merupakan beban bagi pelakunya. Beban tersebut dapat berupa fisik, mental atau sosial. Derajat beratnya beban kerja tidak hanya tergantung pada jumlah kalori yang dikonsumsi, akan tetapi juga bergantung pada jumlah otot yang terlibat pada pembebanan otot statis. Konsumsi energi dapat menghasilkan denyut jantung yang berbeda-beda, selain itu temperatur sekeliling yang tinggi, tingginya pembebanan otot statis serta semakin sedikit otot yang terlibat dalam suatu kondisi kerja dapat meningkatkan denyut jantung, dengan demikian denyut jantung dipakai sebagai indeks beban kerja (Koesyanto, 2008).

Menurut Menpan, pengertian beban kerja adalah sekumpulan atau sejumlah kegiatan yang harus diselesaikan oleh suatu unit organisasi atau pemegang jabatan dalam jangka waktu tertentu. Dari beberapa pengertian mengenai Beban kerja dapat ditarik kesimpulan beban kerja adalah sejumlah kegiatan yang membutuhkan proses mental atau kemampuan yang harus diselesaikan dalam jangka waktu tertentu, baik dalam bentuk fisik maupun psikis (Dhania, 2010).

\section{Beban Kerja Mental}

Beban kerja mental adalah sebuah kombinasi antara faktor-faktor yang terkait dengan tuntutan tugas, kondisi operator dan faktor-faktor waktu (Purwaningsih, 2012). Stres adalah kondisi fisik dan psikologis yang disebabkan karena adaptasi seseorang pada lingkungannya. Selain itu, stres adalah "persiapan yang tidak disadari" oleh seseorang untuk menghindar atau menghadapi tuntutan

tuntutan lingkungannya. Stres akibat kerja didefinisikan sebagai respon emosional dan fisik yang bersifat mengganggu atau merugikan yang terjadi pada saat tuntutan tugas tidak sesuai dengan kapabilitas, sumber daya, atau keinginan pekerja. Seseorang dapat di kategorikan mengalami stres kerja, apabila stres yang dialami melibatkan juga pihak organisasi perusahaan tempat orang yang bersangkutan bekerja. Stres kerja dapat berdampak buruk pada kondisi kejiwaan apabila tidak dilakukan penanggulangan (Kurnia, 2012).

\section{Pengukuran Beban Kerja Mental}

Pengukuran beban kerja mental dapat dilakukan dengan berbagai pendekatan yaitu (Widyanti dkk., 2010):

1. Metode Pengukuran Objektif

Beban kerja mental dapat diukur dengan pendekatan fisologis (karena terkuantifikasi dengan dengan kriteria obyektif, maka disebut metode obyektif). Kelelahan mental pada seorang pekerja terjadi akibat adanya reaksi fungsionil dari tubuh dan pusat kesadaran. Pendekatan yang bisa dilakukan antara lain:
b. Pengukuran selang waktu kedipan mata (eye blink rate).

c. Flicker test.

d. Pengukuran kadar asam saliva.

2. Metode Pengukuran Secara Subjektif

Metode pengukuran beban kerja secara subjektif merupakan pengukuran beban kerja mental berdasarkan persepsi subjektif responden atau pekerja. Berikut ini merupakan beberapa jenis metode pengukuran subjektif:

a. Subjective Workload Assessment Technique (SWAT)

Dalam model SWAT, performansi kerja manusia terdiri dari tiga dimensi ukuran beban kerja yang dihubungkan dengan performansi.

b. NASA TLX

Dalam NASA TLX terdapat 6 dimensi ukuran beban kerja yaitu Mental Demand, Physical Demand, Temporal Demand, Performance, Effort dan Frustation Level.

c. Modified Cooper Harper Scaling.

d. Multidescriptor Scale

Indeks Tugas Tugas NASA (Hart \& Staveland, 1988) menggunakan enam dimensi untuk menilai beban kerja mental: permintaan mental, permintaan fisik, permintaan sementara, kinerja, usaha, dan frustrasi. Skala bipolar Twentystep digunakan untuk mendapatkan penilaian untuk dimensi ini. Prosedur pembobotan digunakan untuk menggabungkan enam penilaian skala individu menjadi nilai global. Prosedur ini memerlukan tugas perbandingan berpasangan yang harus dilakukan sebelum penilaian beban kerja. Perbandingan berpasangan mengharuskan operator memilih dimensi mana yang lebih relevan dengan beban kerja di semua pasangan dari enam dimensi. Frekuensi dimensi yang dipilih lebih relevan adalah bobot skala dimensi untuk tugas yang diberikan untuk operator 
tersebut. Skor beban kerja dari 0 sampai 100 diperoleh untuk setiap tugas penilaian dengan mengalikan berat dengan skala skala dimensi individu, menjumlahkan skala, dan membagi dengan 15 (jumlah total perbandingan berpasangan). (Jose M. Puente, 2004).

Beberapa pengembangan metode NASA TLX, antara lain (Hendrawan dkk., 2014):

1. Kerangka konseptual

Beban kerja timbul dari interaksi antara kebutuhan tugas dan pekerjaan, kondisi kerja, tingkah laku, dan persepsi pekerja (teknisi). Tujuan kerangka konseptual adalah menghindari variabel-variabel yang tidak berhubungan dengan beban kerja. subjektif. Dalam kerangka konseptual, sumber-sumber yang berbeda dan hal- hal yang dapat mengubah beban kerja disebutkan satu demi satu dan dihubungkan.

2. Informasi yang diperoleh

subjektif

dari peringkat (rating)

Peringkat subjektif merupakan metode yang paling sesuai untuk mengukur beban kerja mental dan memberikan indikator yang umumnya paling valid dan sensitif. Peringkat subjektif merupakan satu-satunya metode yang memberikan informasi mengenai pengaruh tugas secara subjektif terhadap pekerja atau teknisi dan menggabungkan pengaruh dari kontributor beban kerja.

3. Pembuatan skala rating beban kerja

a. Memilih kumpulan sub-skala yang paling tepat.

b. Menentukan bagaimana menggabungkan sub-skala tersebut untuk memperoleh nilai beban kerja yang sensitif terhadap sumber dan definisi beban kerja yang berbeda, baik di antara tugas maupun di antara pemberi peringkat.

c. Menentukan prosedur terbaik untuk memperoleh nilai terbaik untuk memperoleh nilai numerik untuk subskala tersebut.

4. Pemilihan sub-skala

Ada tiga subskala dalam penelitian, yaitu

a. skala yang berhubungan dengan tugas, dan skala yang berhubungan dengan tingkah laku (usaha fisik, usaha mental, performansi), skala yang berhubungan dengan subjek (frustasi, stres, dan kelelahan). Susilowati (1999) juga menjelaskan beberapa subskala yang ditulis Hart dan Staveland (1981), antara lain:

b. Skala yang berhubungan dengan tugas peringkat yang diberikan pada kesulitan tugas memberikan informasi langsung terhadap persepsi kebutuhan subjek yang dibedakan oleh tugas. Tekanan waktu dinyatakan sebagai faktor utama dalam definisi dan model beban kerja yang paling operasional, di kuantitatifkan dengan membandingkan waktu yang diperlukan untuk serangkaian tugas dalam eksperimen.

c. Skala yang berhubungan dengan tingkah laku faktor usaha fisik memanipulasi eksperimen dengan faktor kebutuhan fisik sebagai komponen kerja utama. Faktor usaha mental merupaka kontributor penting pada beban kerja pada saat jumlah tugas operasional meningkat karena tanggung jawab pekerja berpindah- pindah dari pengendalian fisik langsung menjadi pengawasan. Peringkat usaha mental berkorelasi dengan peringkat beban kerja keseluruhan dala setiap katagori eksperimen dan merupakan faktor kedua yang paling tinggi korelasinya dengan beban kerja keseluruhan.

d. Skala yang berhubungan dengan subjek frustasi merupakan beban kerja ketiga yang paling relevan. Peringkat frustasi berkorelasi dengan peringkat beban kerja keseluruhan secara signifikan pada semua katagori eksperimen. Peringkat stres mewakili manipulasi yang mempengaruhi peringkat beban kerja keseluruhan dan merupakan skala yang paling independen.

Langkah-langkah pengukuran beban kerja mental dengan menggunakan NASA- TLX adalah sebagai berikut (Hidayat dkk., 2013):

1. Pembobotan hasil kuesioner

Data beban kerja mental dengan menggunakan metode NASA-TLX menggunakan enam indikator yang diukur untuk mengetahui seberapa besar beban kerja mental yang dialami. Indikator tersebut adalah Mental Demand (MD), Physical Demand (PD), Temporal Demand (TD), Performance (P), Frustation level (FR). Sedangkan pembobotan merupakan tahap pemberian bobot yang menyajikan 15 pasangan indikator kemudian diisi oleh responden dengan cara melingkari salah satu pasangan indikator yang lebih dominan.

Tabel 1. Kartu dari metode NASA-TLX 


\begin{tabular}{|c|c|c|}
\hline $\begin{array}{c}\text { Kebutuhan waktu } \\
\text { atau } \\
\text { tingkat frustasi }\end{array}$ & $\begin{array}{c}\text { Kebutuhan fisik } \\
\text { atau } \\
\text { performansi }\end{array}$ & $\begin{array}{c}\text { Performansi } \\
\text { atau } \\
\text { tngkat frustasi }\end{array}$ \\
\hline $\begin{array}{c}\text { Kebutuhan waktu } \\
\text { atau } \\
\text { Tingkat usaha }\end{array}$ & $\begin{array}{l}\text { Tingkat usaha } \\
\text { atau } \\
\text { Performansi }\end{array}$ & $\begin{array}{l}\text { Tingkat usaha } \\
\quad \text { atau } \\
\text { Kebutuhan fisik }\end{array}$ \\
\hline $\begin{array}{c}\text { Kebutuhan Mental } \\
\text { ATAU } \\
\text { Tingkat Usaha }\end{array}$ & $\begin{array}{c}\text { Performansi } \\
\text { ATAU } \\
\text { Kebutuhan Mental }\end{array}$ & $\begin{array}{c}\text { Tingkat Frustasi } \\
\text { ATAU } \\
\text { Kebutuhan } \\
\text { Mental }\end{array}$ \\
\hline $\begin{array}{c}\text { Kebutuhan mental } \\
\text { atau } \\
\text { Kebutuhan fisik }\end{array}$ & $\begin{array}{c}\begin{array}{c}\text { Performansi } \\
\text { atau }\end{array} \\
\text { Kebutuhan waktu }\end{array}$ & $\begin{array}{c}\text { Tingkat frustasi } \\
\text { atau } \\
\text { Tingkat usaha }\end{array}$ \\
\hline $\begin{array}{c}\text { Kebutuhan Waktu } \\
\text { ATAU } \\
\text { Kebutuhan Mental }\end{array}$ & $\begin{array}{c}\text { Kebutuhan Fisik } \\
\text { ATAU } \\
\text { Kebutuhan Waktu }\end{array}$ & $\begin{array}{c}\text { Kebutuhan Fisik } \\
\text { ATAU } \\
\text { Tingkat Frustasi }\end{array}$ \\
\hline
\end{tabular}

2. Pengkategorian penilaian beban kerja Berdasarkan penjelasan Hart dan Staveland (1981) dalam teori Nasa- TLX, skor beban kerja yang diperoleh dapat diintepretasikan sebagai berikut:

Tabel 2. Interval pengkategorian beban kerja mental

\begin{tabular}{|c|l|c|}
\hline No & \multicolumn{1}{|c|}{ Kategori } & Skala Interval \\
\hline 1. & Sangat Rendah & $0-20$ \\
\hline 2. & Rendah & $21-40$ \\
\hline 3. & Sedang & $41-60$ \\
\hline 4. & Tinggi & $61-80$ \\
\hline 5. & Sangat Tinggi & $81-100$ \\
\hline
\end{tabular}

(Sumber: Diniaty, 2016)

\section{Pembobotan Hasil Kuesioner}

Pada tahap ini, pekerja di lantai produksi diminta untuk memilih dengan cara memberikan tanda centang $(\sqrt{ })$ atau menulis salah satu dari dua faktor yang lebih dominan mempengaruhi beban kerja mereka. Hasil pembobotan dapat dilihat seperti berikut :

\begin{tabular}{|c|c|c|c|c|c|c|c|c|c|c|}
\hline No & Faktor & Rl & R2 & R3 & R4 & R5 & R6 & R7 & R8 & Total \\
\hline 1 & Physical Demands & 2 & 4 & 3 & 2 & 3 & 4 & 5 & 4 & 27 \\
\hline 2 & Mental Demands & 3 & 2 & 1 & 3 & 3 & 2 & 2 & 3 & 19 \\
\hline 3 & Tempoxial Demands & 1 & 2 & 3 & 2 & 3 & 1 & 1 & 1 & 14 \\
\hline 4 & Performance & 5 & 3 & 5 & 3 & 2 & 2 & 3 & 2 & 25 \\
\hline 5 & Effort & 4 & 2 & 2 & 3 & 3 & 4 & 4 & 1 & 23 \\
\hline 6 & Frustation & 0 & 2 & 1 & 2 & 1 & 2 & 0 & 4 & 12 \\
\hline & Total & 15 & 15 & 15 & 15 & 15 & 15 & 15 & 15 & \\
\hline
\end{tabular}

Gambar 1. Hasil pembobotan

\section{Pemberian nilai atau skala}

Pemberian rating atau peringkat merupakan tahap setelah pembobotan ditahap sebelumnya. Pada tahap ini, pekerja di lantai produksi diminta untuk memberikan rating antara 1-100 untuk setiap faktor sesuai dengan beban kerja yang dirasakan oleh pekerja di lantai produksi. Hasil pemberian rating dapat dilihat seperti berikut :

\begin{tabular}{|c|c|c|c|c|c|c|c|c|c|c|}
\hline No & Faktor & Rl & R2 & R3 & R4 & R5 & R6 & R7 & R8 & Total \\
\hline 1 & Physical Demands & 100 & 100 & 70 & 80 & 70 & 90 & 80 & 80 & 670 \\
\hline 2 & Mental Demands & 90 & 100 & 80 & 100 & 80 & 100 & 100 & 70 & 720 \\
\hline 3 & Temporial Demands & 100 & 80 & 60 & 80 & 70 & 90 & 80 & 60 & 620 \\
\hline 4 & Performance & 100 & 100 & 90 & 100 & 90 & 80 & 90 & 90 & 740 \\
\hline 5 & Eeffort & 80 & 100 & 90 & 80 & 80 & 100 & 100 & 70 & 700 \\
\hline 6 & Erustation & 80 & 60 & 70 & 80 & 60 & 80 & 80 & 60 & 570 \\
\hline
\end{tabular}

Gambar 2. Hasil rating

\section{Perhitungan Weigted Workload (WWL)}

Nilai WWL merupakan nilai beban kerja mental yang dirasakan oleh pekerja di lantai produksi pabrik kelapa sawit PT Bina Pratama Sakato Jaya. Penentuan skala tinggi atau rendah beban kerja mental bisa berdasarkan subjektifitas seseorang. Menghitung WWL bertujuan untuk mendapatkan nilai dari beban kerja mental tiap faktor. 


\begin{tabular}{|c|c|c|c|c|c|c|c|c|c|}
\hline $\mathrm{N}_{0}$ & Faktor & $\mathrm{Rl}$ & $\mathrm{R} 2$ & $\mathrm{R}^{3}$ & $\mathrm{R} 4$ & $\mathrm{R} 5$ & $\mathrm{R} 6$ & $\mathrm{R} 7$ & R8 \\
\hline 1 & $\begin{array}{l}\text { Physical } \\
\text { demand }\end{array}$ & 200 & 160 & 210 & 160 & 210 & 360 & 400 & 320 \\
\hline 2 & Mental demand & 270 & 200 & 80 & 300 & 180 & 200 & 200 & 210 \\
\hline 3 & $\begin{array}{l}\text { Temporial } \\
\text { demand }\end{array}$ & 100 & 160 & 180 & 160 & 240 & 90 & 80 & 60 \\
\hline 4 & Performance & 500 & 300 & 450 & 190 & 180 & 180 & 270 & 180 \\
\hline 5 & Effort & 320 & 200 & 180 & 240 & 240 & 400 & 320 & 70 \\
\hline 6 & Frustation & 0 & 120 & 70 & 140 & 60 & 16 & 0 & 240 \\
\hline \multicolumn{2}{|c|}{ Total WWL } & 1390 & 1140 & 1170 & 1190 & 1110 & 1390 & 1270 & 1080 \\
\hline \multicolumn{2}{|c|}{ Skor WTL } & 92,6 & 76,0 & 78,0 & 77,3 & 74,0 & 92,6 & 84,6 & 72,0 \\
\hline \multicolumn{10}{|c|}{ Sumber : PT. Bina Pratama Sakato java (2017) } \\
\hline
\end{tabular}

Gambar 3. Hasil WWL

\section{Pengkategorian Penilaian Beban Kerja}

Kategori penilaian beban kerja terdiri dari tiga tingkatan, yaitu rendah dengan skala interval $0-9$, sedang dengan skala interval $10-29$, agak tinggi dengan skala interval $30-49$, tinggi dengan skala interval $50-79$ dan sangat tinggi dengan skala interval $80-100$. Berikut ini adalah pilihan kategori penilaian Beban Kerja.

Tabel 3. Kategori Penilaian Beban Kerja

\begin{tabular}{|c|c|c|c|}
\hline No & Stasiun & $\begin{array}{c}\text { Nilai } \\
\text { Beban } \\
\text { Kerja }\end{array}$ & Kategori \\
\hline 1 & $\begin{array}{c}\text { Loading } \\
\text { ramp }\end{array}$ & 92,6 & $\begin{array}{c}\text { Sangat } \\
\text { Tinggi }\end{array}$ \\
\hline 2 & Perebusan & 76,0 & Tinggi \\
\hline 3 & Tippler & 78,0 & Tinggi \\
\hline 4 & Thereshing & 77,3 & Tinggi \\
\hline 5 & Press & 74,0 & Tinggi \\
\hline 6 & Klarifikasi & 92,6 & $\begin{array}{c}\text { Sangat } \\
\text { Tinggi }\end{array}$ \\
\hline 7 & $\begin{array}{c}\text { Nut dan } \\
\text { Kernel }\end{array}$ & 84,6 & $\begin{array}{c}\text { Sangat } \\
\text { Tinggi }\end{array}$ \\
\hline 8 & Boiler & 72,0 & Tinggi \\
\hline
\end{tabular}

Sumber : PT. Bina Pratama Sakato jaya (2017)

\section{Analisa}

\section{Stasiun Loading Ramp}

Berdasarkan perhitungan beban kerja mental yang dilakukan pada Stasiun Loading Ramp adalah sebesar 92,6. Maka berdasarkan nilai tersebut, beban kerja mental pada operator Stasiun Loading Ramp termasuk dalam beban kerja sangat tinggi. Faktor dominan yang sangat mempengaruhi dalam penentuan beban kerja mental ini adalah performansi

\section{Stasiun Perebusan}

Berdasarkan perhitungan beban kerja Mental yang dilakukan, beban kerja mental pada Stasiun perebusan adalah sebesar 76. Maka berdasarkan nilai tersebut, beban kerja mental pada operator Stasiun Loading Ramp termasuk dalam beban kerja yang tinggi. Performansi menjadi faktor yang mendominasi dalam penentuan beban kerja operator Stasiun perebusan.

\section{Stasiun Tippler}

Berdasarkan perhitungan beban kerja yang dilakukan, beban kerja mental pada Stasiun Tippler adalah sebesar 78 . Maka berdasarkan nilai tersebut, beban kerja mental pada operator Stasiun Tippler termasuk dalam beban kerja yang tinggi. Faktor yang mendominasi pada penilaian beban kerja mental adalah performansi

\section{Stasiun Threshing}

Berdasarkan perhitungan beban kerja yang dilakukan, beban kerja mental pada Stasiun Threshing adalah sebesar 77,3. Maka berdasarkan nilai tersebut, beban kerja mental pada operator Stasiun Threshing termasuk dalam beban kerja yang tinggi. Faktor yang menjadi dominan pada Stasiun Treshing adalah kebutuhan mental.

\section{Stasiun Press}

Berdasarkan perhitungan beban kerja mental yang dilakukan, beban kerja mental pada Stasiun Press adalah sebesar 74. Maka berdasarkan nilai tersebut beban kerja mental pada operator Stasiun Press termasuk dalam beban kerja yang tinggi. Kebutuhan mental dan usaha menjadi faktor yang dominan pada operator Stasiun Pres.

\section{Stasiun Klarifikasi}

Berdasarkan perhitungan beban kerja mental yang dilakukan pada Stasiun klarifikasi adalah sebesar 92,6. Maka berdasarkan nilai tersebut, beban kerja mental pada operator Stasiun klarifikasi termasuk dalam beban kerja sangat tinggi. Faktor yang mendominasi pada penilaian beban mental operator Stasiun klarifikasi ini adalah Usaha.

\section{Stasiun Nut dan Kernel}

Berdasarkan perhitungan beban kerja mental yang dilakukan pada Stasiun nut dan kernel adalah sebesar 84,6. Maka berdasarkan nilai tersebut, beban kerja mental pada operator Stasiun Nut dan Kernel termasuk dalam beban 
kerja yang sangat tinggi. Faktor yang mendominasi pada penilaian beban mental operator Stasiun Nut dan Kernel adalah Kebutuhan Fisik.

\section{Stasiun Boiler}

Berdasarkan perhitungan beban kerja mental yang dilakukan pada Stasiun Boiler adalah sebesar 72. Maka berdasarkan nilai tersebut beban kerja mental pada operator Stasiun Boiler termasuk dalam beban kerja tinggi. Faktor yang mendominasi pada penilaian beban mental operator Stasiun Boiler adalah Kebutuhan Fisik

\section{Analisis Pengaruh Terhadap Setiap Stasiun Lantai Produksi}

Kategori atau faktor yang paling berpengaruh pada Semua stasiun lanta Produksi dengan melakukan penilaian beben kerja mental dengan menggunakan NASA-TLX ini adalah Kebutuhan Fisik, Performansi, Kebutuhan Mental dan Usaha berdasarkan hitungan WWL dari hasil pembobotan kuesioner NASA-TLX.

\section{Kesimpulan}

Berdasarkan hasil pengolahan data dengan pengukuran menggunakan metode NASA-TLX menunjukkan hasil pengkategorian beban kerja mental dapat diketahui operator yang memiliki beban kerja yang tergolong sangat tinggi yaitu pada stasiun Loading Ramp 92,6 \%, Klarifikasi 92,6 \% dan Nut dan Kernel 84 \%, sedangkan operator yang memiliki beban kerja mental tergolong tinggi pada stasiun Perebusan $76 \%$, pada stasiun Tippler $78 \%$, pada stasiun Thereshing 77,3\%, pada stasiun Press $74 \%$ dan pada stasiun Boiler 72. Karena rata-rata beban kerja yang dialami tergolong tinggi, peneliti memberikan alternatif perbaikan diantaranya menambah karyawan dilantai produksi dan diberikan pelatihan-pelatihan tentang kondisi pabrik dan kondisi mesin yang ada pada lantai produksi.

\section{Daftar Pustaka}

[1] Andriyanto, Bariyah Choirul. Analisis Beban Kerja Operator Mesin Pemotong Batu Besar (Sirkel 160 Cm) Dengan Menggunakan Metode 10 Denyut. Jurusan Teknik Industri, Universitas Ahmad Dahlan Yogyakarta, 2012.

[2] Astuty, Miranti Siti. Tingkat Beban Kerja Mental Masinis Berdasarkan NASA-TLX (Task Load Index) Di PT. KAI Daop. II Bandung. Jurusan Teknik Industri Itenas Bandung, 2013.
[3] Diniaty Dewi, Mulyadi Zukri. Analisis Beban Kerja Fisik Dan Mental Karyawasn Pada Lantai Produksi Dipt Pesona Lancang Kuning. Teknik Industri, Fakultas Sains dan Teknologi, Universitas Islam Negeri Sultan Syarif Kasim Riau, 2016.

[4] Hidayat T. Fariz, Pujangkoro Sugiharto, Anizar. Pengukuran Beban Kerja Perawat Dengan Menggunakan Metpde NASA-TLX Dirumah Sakit XYZ. Teknik Industri, Fakultas Teknik, Universitas Sumatera Utara, 2013.

[5] Koesyanto Herry. Hubungan antara Beban Kerja Dengan Kelelahan Kerja Mengajar Pada Guru Sekolah Dasar Se-Kecamatan Semarang Barat Tahun Ajaran 2006/2007. Jurusan IKM FIK Universitas Negeri Semarang, 2008.

[6] Lubis Iskandar, Yohansyah Monika Willy. Analisis Produktivitas Kelapa Sawit (Elaeis guineensis Jacq) di PT. Perdana Inti Sawit Perkasa I Riau. Departemen Agronomi dan Hortikultura, Fakultas Pertanian, Institut Pertanian Bogor, 2014.

[7] Mutia Mega. Pengukuran Beban Kerja Fisiologis Dan Psikologis Pada Operator Pemetikan Teh Dan Operator Produksi Teh Hijau Di PT. Mitra Kerinci. Jurusan Teknik Industri, Fakultas Teknik, Universitas Andalas, Padang, 2014.

[8] Puente M.Jose, Martin Jesus, Diaz Eva, Rubio Susana. Evaluation of Subjective Mental Workload: A Comparison of SWAT, NASA-TLX, and Workload Profile Methods. Department of Differential and Work Psychology, Faculty of Psychology, Universidad Complutense de Madrid, 2004.

[9] Soleman, Aminah. Analisis Beban Kerja Ditinjau dari Faktor Usia dengan Pendekatan Recommended Weight Limit. Universitas Patimura, 2011.

[10] Widyanti, Ari dan Jhondon, Addie. Pengukuran Beban Kerja Mental dalam Searching Task dengan Metode Rating Scale Mental Effort (RSME). Institut Teknologi Bandung, 2015. 